\title{
Ekologinis saugumas Lietuvoje: esama padètis ir problemos
}

\begin{abstract}
2006 m. ekologinių rizikos veiksnių kitimo tendencijos Lietuvoje buvo panašios kaip ir 2005 m. Rizikos veiksniai atmosferos saugos sektoriuje, kurie veikẻ šalies ekologinę būklę, tebėra intensyviai didëjantis automobilių skaičius, neefektyvios miestų eismo reguliavimo sistemos, aplinkkeliu stoka. Vandens vartojimo saugos sektoriuje: susidèvejję centralizuoti vandens tiekimo tinklai, netinkamos kokybės geriamas vanduo, nepatenkinama kastinių šulinių vandens kokybẻ. Lietuvos Ekologinio saugumo užtikrinimo programos vienas iš tikslų - sumažinti ekologinio pavojaus riziką, užkirsti kelią neigiamam aplinkos poveikiui ir įtvirtinti valstybès politikos prioritetus ekstremaliu situaciju prevencijos srityje.

Valstybės prioritetams iggyvendinti svarbiausiais išlieka uždaviniai, kurie užtikrintų ekologinį saugumą, garantuotų darnią ūkio plètrą ir sumažintų neigiamą ekstremalios situacijos poveikị aplinkai ir gyventojams. Objektyvios informacijos apie ekologinį saugumą skleidimas, patikimos informacijos rinkimas, analizè ir teikimas visuomenei skatins bendradarbiavimą su kaimyninėmis valstybėmis ekologinio saugumo ir taršos prevencijos srityse. Tikslams pasiekti būtina sudaryti teisines ir organizacines sąlygas optimaliam atsakingu instituciju tarpusavio veiksmu koordinavimui, valdymui ir kontrolei, siekiant užtikrinti ekologinį saugumą.
\end{abstract}

\section{Ivadas}

Mokslo ir technikos pažanga bei žmogaus galimybės veikti gamtą pradejjo viršyti gebëjimus suprasti ir ịvertinti galimas šios veiklos pasekmes. Spartus ekonomikos augimas (ūkio plètra) išryškino globalias problemas, kurios atspindi ekonominio, politinio ir dvasinio gyvenimo situaciją Lietuvoje. Šiandieninė politika turi užtikrinti, kad vienos žmonių kartos veiklos kaštai nesudarytų pavojaus ateities kartu galimybėms, nes kai kurie aplinkos ir socialinių sistemų kertiniai bruožai juos pažeidus negali būti lengvai atkurti ${ }^{1}$. Žala gamtai ir aplinkai kaip ekonominès plètros padarinys yra viena iš pagrindiniu problemu.

\footnotetext{
* Irena Gavéniene - aplinkos saugos ekspertè, Vilniaus universiteto Tarptautinès verslo mokyklos dėstytoja. Adresas: Saulėtekio al. 22, 10225 Vilnius, tel. (8-5) 2732882, el. paštas - irena@gavenas. com

${ }^{1}$ Čiegis R., „Ekologinis saugumas: nauji iššūkiai planetai“, Strategine savivalda - Strategiu Self-Management, 2006 Nr. 1(3), http:/ / www.Eksponente.lt/ssz .
} 
$2003 \mathrm{~m}$. Vyriausybė patvirtino Nacionalinę darnaus vystymosi strategiją. Strategijoje pripažistama, kad aplinkos sauga yra vienas svarbiausių šalies plètros komponentų. Pagrindinis Lietuvos siekis, igyvendinant darnios plètros tikslus, yra pagal ekonominius, socialinius bei gamtos išteklių naudojimo efektyvumo rodiklius pasiekti dabartinį ES šaliu vidutinį lygị, o pagal aplinkos taršos rodiklius neviršyti ES leistinų normatyvų bei igyvendinti tarptautiniu konvenciju, ribojančių aplinkos teršimą ir indèli i globalinę klimato kaitą, reikalavimus. Tačiau šiuolaikinè industrinè visuomenè ir jos plètros modelis yra aiškiai nedarnūs, nes ekonominëje veikloje remiamasi neatsinaujinančiais ištekliais ir iškastiniu kuru, gamtinių išteklių naudojimas yra akivaizdžiai per didelis, pajamos ir ištekliai tarp gyventoju pasiskirstę netolygiai, o pajamu atotrūkis tarp industrinių ir besivystančių šalių vis didejja, pasmerkdamas apie 3 milijardus žmonių skurdui. Taigi ekonominė plètra išryškino globalines problemas - skurdą bei karinius konfliktus. Visuomenės vystymosi metu išryškèję neigiami aspektai stiprina vienas kitą. Skurdas skatina žmones pereksploatuoti aplinką (svarbiausias ilgalaikis ryšys tarp skurdo ir aplinkos degradacijos besivystančiose šalyse jau buvo pripažintas 9-ojo dešimtmečio pabaigoje ir tapo svarbiausiu iššūkiu darniam vystymuisi), skurdas veda į konfliktą, konfliktai veda į aplinkos pažeidimą ir jos ribotumo augimą, o pažeista aplinka ir ribotumas veda ị socialinị konfliktą. Todèl ekologiniu problemų atsiradimą reikia nagrinèti kaip atgalinių ryšių pasireiškimą ekonominëje, socialinëje ir aplinkosauginëje sistemoje ${ }^{2}$.

Lietuvos Respublikos nacionalini saugumą užtikrinantys vidiniai ir išoriniai veiksniai iš esmès nepakito, todèl galima teigti, kad socialinè ekonominè plètra sudaro prielaidas užtikrinti visuomenès stabilumą ir sumažinti išoriniu grèsmiu galimybes. $2006 \mathrm{~m}$. ekologiniu veiksnių kitimo tendencijos išliko panašios (užterštu teritoriju sutvarkymo bei sąvartynu, neatitinkančiu ES reikalavimu, gausa; liko neišspręsta centralizuotų vandens tiekimo tinklų susidèvẻjimo problema; aplinkkelių stoka; aplinkos oro tarša ir kt.). Pagrindinėmis išorinėmis grėsmėmis tebėra trumpalaikès gaivalinės nelaimės: liūtys, smarkūs vẻjai, audros, ilgalaikiai šalčiai bei augantis gaisrų atvirose teritorijose skaičius (2006 m. išaugo 2,4 karto).

Spartus ekonomikos augimo derinimas su sveikos aplinkos išsaugojimu yra nelengvai išsprendžiamas uždavinys, nes dažniausiai visuomenè yra linkusi pagrindini prioritetą suteikti ekonominiu problemų sprendimui, o aplinkos kokybė nukenčia. Dabartiniame Lietuvos raidos etape svarbu laiku igyvendinti efektyvias aplinkos saugos priemones ir mažinti neigiamą energijos ir gamtos išteklių naudojimo bei ūkinès veiklos poveikị aplinkai. Susikaupusių aplinkos problemų sprendimas kainuoja daug brangiau nei ju prevencija ir anksčiau ar vèliau pradeda stabdyti ekonomikos augimą. Taigi siekiant užtikrinti geresnę aplinkos kokybę ir darnų vystymąsi dėmesį ir lëšas reikia skirti prioritetinėms aplinkos apsaugos kryptims, pirmiausia - taršos prevencijai.

${ }^{2}$ Ten pat 


\section{Aplinkos būklè}

Lietuvos Respublikos teritorijos geografinė padètis ir struktūra yra palanki darniai visuomenės raidai, gamtos sąlygos nekelia pavojaus tautos ir valstybès egzistencijai. Pastaraisiais metais daugiau kaip 50 \% sumažèjo teršalu, patenkančiu i i paviršinius vandens telkinius, kiekis (paviršinio, požeminio vandens telkiniai ir Baltijos jūros teritoriniai vandenys sudaro apie $413 \mathrm{kv}$. metrų). Tačiau tik $40 \%$ nuotekų išvaloma iki nustatytų normatyvų ( $2005 \mathrm{~m}$. duomenys), nes didžioji dalis nuotekų valymo įrenginių yra fiziškai ir morališkai pasenę. Esamiems 50-70 metu senumo vandens tiekimo tinklams reikia renovacijos, kitaip nebus užtikrinta centralizuotai tiekiamo geriamo vandens kokybė. O dèl prasto vandens gali padidèti pavojus gyventojų sveikatai. İmonė vienam produkcijos vienetui pagaminti sunaudoja vidutiniškai 1,5-2 karto daugiau energijos, žaliavų ir vandens negu ES valstybiu įmonės.

Teršalų, išmetamu i a aplinkos orą iš stacionarių taršos šaltinių, kiekis pastarajįi dešimtmeti sumažẻjo apie 60 proc., tačiau daugelis Lietuvoje esančiu lengvuju automobilių vis dar senesni nei 10 metu, pasenusios ir neefektyvios eismo reguliavimo sistemos, aplinkkelių stoka didina miestų oro taršą ir triukšmą. Tai ypatingai jaučiama centrinėse miestų dalyse. Nẻra gamtinių dujų saugyklu, o dujos tiekiamos iš vienintelio šaltinio (90\%), todèl egzistuoja grẻsmė, kad, sumažinus dujų tiekimą arba padidinus jų kainą, bus naudojamas taršesnis kuras. Gamybinès energijos sąnaudos ir oro tarša BVP vienetui pagaminti iki 2 kartų didesné nei kitose ES valstybèse.

Kasmet susidaro apie 3,5 mln. tonų nepavojingų atliekų ir apie 110 tūkst. tonų pavojingų atliekų. Didžioji dalis atlieku šalinama sąvartynuose, menkai išplètota komunalinių atliekų tvarkymo sistema, daugelis veikiančių sąvartynų neatitinka aplinkos saugos reikalavimų. Grėsmę kelia buityje susidarančios pavojingos atliekos, kurios dažnai šalinamos kartu su nepavojingomis atliekomis. Igyvendinant pesticidų atliekų tvarkymo Lietuvos Respublikoje 2002-2005 m. programą į Vokietiją išvežta nukenksminti 1023 tonų senų pesticidų (57 senu pesticidų sandèliai sutvarkyti ir nukenksminti). Tačiau iki galo neišspręstos galvaninių elementu, medicininių atlieku, pavojingu pramonès atliekų tvarkymo problemos ${ }^{3}$.

Didžiausi aplinkos taršos radionuklidais šaltiniai Lietuvoje yra Maišiagalos radioaktyviujų atliekų saugykla ir Ignalinos atominė elektriné (IAE). Kiekvienais metais fiksuojamos techninės avarijos bei gaivaliniai reiškiniai, kuriu metu nustatomas neigiamas poveikis aplinkai ar žmonių sveikatai. Šalyje yra daugiau nei 930 potencialiai pavojingų objektų ir 465 hidrotechniniai statiniai. Kiekvienais metais registruojama iki 140 ivvykiu, kuriu metu buvo padaryta žala aplinkai ar žmonių sveikatai, 50 ịvykių registruojami kaip ekstremalūs (daugiausia avarijos ịvyksta gabenant ir saugant chemines medžiagas, naftą ir jos produktus). Sausros metu užregistruojama virš 1000 durpynų, durpingu

\footnotetext{
${ }^{3}$ Lietuvos Respublikos Seimo nutarimas, Dél ekologinio saugumo užtikrinimo programos patvirtinimo, Valstybės žinios, 2005-10-01, Nr. 117-4226.
} 
pievų ir mišku gaisru, miškuose pastoviai registruojami miško kenkëjų ir ligu pažeisti plotai, karstiniame regione (Lietuvos šiaurejje) dèl aktyvių karstiniu reiškinių kasmet atsiranda iki 70 naujų igriuvu, dèl globalinès klimato kaitos dažnẻja stichiniai ir katastrofiniai reiškiniai (potvyniai, žemės drebejjimai, sausros ir kt.), kurie daro žalą aplinkai, žmonėms ir šalies ūkio plètrai. Kasmet Nemuno žemupyje fiksuojami didelius plotus užliejantys potvyniai.

Chemijos pramonè - viena didžiausių ir svarbiausių ES ūkio šaku, sukurianti būtinus produktus kitiems sektoriams bei prisidedanti prie ES ekonominès plètros. Dabartinis ES cheminių medžiagų naudojimo reguliavimas yra kritikuojamas kaip nepalankus ekonomikai augti, stabdo inovacijų diegimą ir neužtikrina efektyvios chemikalų grèsmių kontrolès. Esamas grèsmių vertinimo procesas užtrunka ilgai, o kasmetinis vertinimas apima tik kai kurias chemines medžiagas. Šiuo metu labiau kreipiamas dèmesys į naujai atsirandančių, o ne į rinkoje jau esančių medžiagų keliamas grèsmes (naujomis laikomos $1981 \mathrm{~m}$. i rinką pateiktos medžiagos - iš viso apie 3 tūkst. rūšių; iki 1981 m. pradètú naudoti chemikalų yra daugiau nei 100 tūkst.). Icdiegus cheminių medžiagu registracijos, įvertinimo, autorizacijos ir apribojimu sistemą (ang. reach) bus apsaugoti nuo žalingo poveikio žmonès, ju sveikata ir aplinka. Ši sistema užtikrins vienodus reikalavimus visoms cheminėms medžiagoms. Norédami jas gaminti ar pateikti į ES rinką gamintojai bei importuotojai privalès įvertinti galimas medžiagu grèsmes ir nustatyti priemones grėsmėms šalinti.

\section{Gamtos išteklių tausojimas - ekologinio saugumo ir darnios ekonomikos plètros garantas}

Gamtos išteklių tausojimas suprantamas kaip išteklių naudojimas, atsižvelgiant į aplinkos saugos, ekonominius ir socialinius visuomenės tikslus, sudarant galimybę pasiekti visuotinę gerovę dabartinei ir ateinančioms kartoms, neperžengiant leistinu poveikio aplinkai ribų. Taigi būtina sudaryti palankias sąlygas racionaliam gamtos išteklių naudojimui, jų saugai, atkūrimui ir gausinimui. Jei norima, kad augtų ekonomika, reikia tausoti išteklių naudojimą: prekių ir paslaugu apimtys turi didèti dvigubai greičiau negu gamtos išteklių naudojimas joms kurti. Lietuvoje sudarytos teisinès ir ekonominès prielaidos, skatinančios tausoti išteklių naudojimą, apsaugą, poveikio aplinkai mažinimą, energijos efektyvumo ir atsinaujinančių energijos išteklių naudojimo didinimą, tačiau aplinkos kokybė dar neatitinka reikalavimu, keliamų darniai ūkio plètrai.

Vandens ištekliai lemia ūkio vystymosi galimybes ir sąlygas. Vanduo yra svarbiausias veiksnys, sąlygojantis visų ekosistemų būklę, todèl gera jo kokybẻ lieka viena svarbiausia sąlyga, jei norima užtikrinti tiek nacionalinį saugumą, tiek ir ekologini saugumą. Apie 64 \% Lietuvos paviršinių vandens telkinių yra 
paveikti antropogeninès veiklos. Blogai išvystyta paviršinių (lietaus) nuoteku tvarkymo infrastruktūra, todèl didelè jų dalis į paviršinius vandens telkinius patenka nevalytos ir labai veikia vandens telkinių būklę.

Požeminis vanduo kaip žemès gelmių išteklius yra pagrindinis geriamojo vandens šaltinis Lietuvoje, todèl jo apsauga yra viena svarbiausių ekologinio saugumo užtikrinimo priemonių. Gruntinis vanduo menkai apsaugotas nuo antropogeninio poveikio, pagrindiniu teršẻju išlieka pasklidieji taršos šaltiniai. Geriamojo vandens kokybe lieka aktuali kaimo vietovėse, kur naudojamas kastinių šulinių vanduo. Apie $1 \mathrm{mln}$. Lietuvos gyventojų vartoja šachtinių šulinių vandeni, kurio vanduo dažnai užterštas nitratais ir kelia pavojų žmonių sveikatai.

Lietuvos Respublikos Konstitucija iૃteisina išimtinę valstybės gelmiu nuosavybę, pabrèždama žemės gelmių išteklių svarbą valstybės gyvenime. Naudinguju iškasenu gausa ir gebejimas jomis pasinaudoti lemia šalies vystymosi mastą ir spartą, gyvenimo lygị. Šiuo metu Lietuvoje yra ištirta 17 rūšių naudinguju iškasenu, iš kurių 9 rūšys (klintis, dolomitas, smèlis, žvyras, molis, kreidos mergelis, sapropelis ir nafta) eksploatuojamos. Vien tik detaliai išžvalgytų naudingujų iškasenų sąlyginė vertė $2006 \mathrm{~m}$. sudarė $56 \mathrm{mlrd}$. litų. Tai daugiausia statybinių medžiagų pramonei ar kelių tiesimui skirtos naudingos iškasenos, kurios pasaulyje pagal sunaudojimo kieki ( $22 \mathrm{mlrd}$. tonų - daugiausia iš visų išteklių) ir ekonominę vertę (nusileidžia tik naftai, dujoms ir akmens angliai) yra vienos iš svarbiausių. Kyla pavojus, kad plečiantis statybų verslui iškasamų naudingujų iškasenų kiekis, tenkantis vienam gyventojui, gali dar didèti (dabar tenka apie 4 tonų vienam gyventojui) ir pasiekti industrinių šalių lygị (20 tonų vienam gyventojui), o tai sukeltų grèsmę tiek nacionaliniam, tiek ekologiniam saugumui.

Mišku ištekliai Lietuvoje yra pakankamai subalansuoti visuomenės reikmėms tenkinti ir mišku ūkio veiklai plèsti. Šiuo metu miškai užima apie $2,12 \mathrm{mln}$. ha plotą (32,5\%) šalies teritorijos ir miškingumas pastaraisiais metais nuolat didëja. Tačiau Lietuvos miškai kasmet pažeidžiami įvairių veiksnių. Gaisrų daromai žalai sumažinti šalyje sukurta ir nuolat palaikoma valstybine miško priešgaisrinių priemonių sistema, tačiau išvengti gaisru ir apsaugoti gamtą nuo gaisro ir jo pasekmių darosi vis sudètingiau dèl neprognozuojamos žmonių veiklos, kuri kelia pavojų gamtinei aplinkai.

Žuvų ištekliai yra vieni svarbiausių maisto ir rekreacinių išteklių. Lietuvos jūrų žvejybos rajonai yra Atlanto vandenynas ir Baltijos jūra. Iš viso šiuose vandenyse sugaunama apie 150 tūkst. tonų žuvu, nors Baltijos jūroje ES Taryba Lietuvai skiria apie 30 tūkst. tonų metinių žvejybos kvotų. Dèl neišplètotos žvejybos infrastruktūros, augančių kuro kainų, nestabilių žvejybos partnerystès santykių su trečiosiomis šalimis, mažẻjančių kai kurių žuvų rūšių išteklių sugaunama tik apie pusė kiekio. Šviežių žuvų pasiūla netenkina šalies vartotoju poreikio.

Gamtinės aplinkos ištekliai - biologinè įvairovè ir gamtinis kraštovaizdis, kaip sveikos gyvensenos aplinką sąlygojančių rekreacinių išteklių pagrindas, išlieka vienas svarbiausių Lietuvos išteklių. Biologinei įvairovei kelia grèsmę 
besikeičiančios ūkininkavimo tradicijos žemės ir miškų ūkyje, invazinių rūšiu plitimas. Labai svarbi Baltijos jūros kranto apsauga, nes pasaulinė klimato kaita, vandenyno lygio kilimas, smèlio išteklių mažẻjimas skatina krantų ardymą. Didelę įtaką Lietuvos Baltijos jūros krantų raidai turi jūros industrijos plètra, neigiamai veikianti krantodaros procesus.

Lietuva importuoja beveik $90 \%$ pirminės energijos. Viena rimčiausių neefektyvaus energijos išteklių vartojimo priežasčių Lietuvoje yra ta, kad daugumos viešosios paskirties pastatu šiluminès savybės yra labai prastos ir reikalauja daug energijos šildyti. Mažai išvystytas ekologiškai švarių atsinaujinančių energijos išteklių, tokių kaip geoterminè (žemės gelmių šiluminė energija) ir vëjo energija, panaudojimas šilumos ir elektros gamybai ${ }^{4}$.

Igyvendinant nacionalinio saugumo reikalavimus, kai ekologinio saugumo rizikos veiksniai yra tokie aktualūs, pagrindine užduotimis išlieka ilgalaikis ir racionalus valstybės funkcionavimui svarbių nacionalinių išteklių naudojimo, apsaugos, gausinimo užtikrinimas, sudarant sąlygas darniai ūkio plètrai.

\title{
3.Grèsmès ekologiniam saugumui šaltiniai ir aplinkos apsaugos priemonès
}

\author{
Grèsmès ekologiniam saugumui gali būti:
}

- techninio pobūdžio (pvz., avarija IAE; avarijos kaimyninių valstybiu atominèse jègainèse ir didžiausiuose pramonés objektuose; avarijos pramonės įmonėse, sandèliuose arba kituose statiniuose, kuriuose nuolat arba laikinai gaminamos, perdirbamos, laikomos, sandèliuojamos pavojingos cheminès medžiagos ir preparatai arba tvarkomos jų atliekos; gaisrai objektuose, kuriuose galimas sprogimo pavojus; avarijos transporte, kuriuo vežamos radioaktyviosios ar kitos pavojingos cheminės medžiagos, preparatai ir jų atliekos; avarijos dujotiekyje; hidrotechniniu statiniu griūtys; naftos gavyba Baltijos jūroje);

- gamtinio pobūdžio grèsmės (pvz., stichiniai, katastrofiniai hidrometeorologiniai reiškiniai; pavojingi geologiniai procesai; išplitę gaisrai miškuose ir durpynuose; augalų kenkẻjų antplūdžiai);

- socialinio pobūdžio (pvz., pavojingų užkrečiamuju ligų protrūkiai ir endeminiai užkrečiamujų ligų židiniai);

- kriminalinio pobūdžio (pvz., teroro ir diversijos aktai).

Iškilus minėtoms grėsmėms gali nukentėti Lietuvos gyventojai, gyvūnija, augalai, gali būti užterštas aplinkos oras, vanduo, dirvožemis. Taigi ekologinis saugumas yra veiksmų ir priemonių visuma, užtikrinanti sveiką ir švarią aplinką, minimalų neigiamą poveikį aplinkai ir žmonių sveikatai, žalos aplinkai ir

\footnotetext{
${ }^{4}$ Lietuvos Respublikos Seimo nutarimas, Dél gamtos ištekliu tausojimo ir apsaugos programos patvirtinimo, Valstybès žinios, 2007-03-10, Nr. 30-1095.
} 
žmonėms prevenciją. Todèl vandens apsaugos srityje būtina modernizuoti ir išplèsti esamus, statyti naujus ES reikalavimus atitinkančius nuotekų valymo įrenginius, renovuoti nuotekų surinkimo sistemą; modernizuoti geriamojo vandens viešojo tiekimo tinklo infrastruktūrą; igyvendinti technines ir organizacines priemones, leidžiančias aprūpinti gyventojus geros kokybės geriamuoju vandeniu; modernizuoti vandens išteklių stebėsenos, laboratorinių tyrimu, duomenu kaupimo ir analizès sistemą.

Atmosferos apsaugos srityje, taikant apyvartinių taršos leidimų sistemą, pasiekti, kad atmosfera būtų mažiau teršiama šiltnamio efektą sukeliančiomis dujomis; dideliuose deginimo įrenginiuose taikyti naujausias technologijas ir naudoti deginimo produktų valymo įrenginius; sukurti transporto priemoniu keliamos taršos kontrolès sistemą, įteisinti ekonomines ir administracines transporto priemonių keliamos taršos reguliavimo priemones; įdiegti modeliavimu pagricstos atmosferos kokybès stebésenos sistemą ${ }^{5}$.

Atliekų tvarkymo srityje reikia uždaryti ES reikalavimų neatitinkančius sąvartynus ir sukurti modernias regionines komunalinių atliekų tvarkymo sistemas; sukurti pavojingų atliekų tvarkymo sistemą, užtikrinančią aplinkai ir žmonių sveikatai saugų pavojingų atliekų tvarkymą; parengti energijos gamybos iš atlieku programą ir pradèti ją igyvendinti; taikyti šiuolaikines panaudoto branduolinio kuro tvarkymo ir saugojimo technologijas, analizuoti galimybes jị laidoti, plèsti šiuolaikinèmis technologijomis pagrįstą radioaktyviuju atliekų tvarkymo infrastruktūrą.

Ekstremalių situacijų valdymo srityje įvertinti, kaip šalies atsakingos institucijos pasirengusios reaguoti į ekstremalias situacijas, tobulinti šią veiklą; padidinti sausros ir potvynio Nemuno žemupyje prognozavimo efektyvumą; įrengti seismologines stotis, atlikti Lietuvos seismingumo analizę ir atskirti pagal rajonus; užtikrinti tvenkinių hidrotechnikos statinių tinkamą naudojimą ir priežiūrą; parengti miškų ir durpynų gaisru prevencijos priemones; ištyrinèti požemines karstines tuštumas ir sudaryti Šiaurès Lietuvos karstinio regiono karstinių tuštumų žemėlapi, užtikrinti ekologiškai saugią urbanistinę plètrą karstinių reiškinių požiūriu; gerinti operatyvumą ir efektyvumą likviduojant ekstremaliu įvykiu padarinius ir kt. Naudojant prevencines priemones, tinkamai kontroliuoti galimus grèsmės ekologiniam saugumui šaltinius.

\section{Radiacinès ir branduolinès saugos užtikrinimas}

Prioritetinè nacionalinio saugumo kryptis 2006 m. Lietuvoje - apsauga nuo radiacinio pavojaus, užtikrinant branduolinę, radiacinę saugą, užkertant kelią galimiems terorizmo atvejams, nelegaliam branduolinių ir radioaktyviu

\footnotetext{
${ }^{5}$ Lietuvos Respublikos aplinkos ministerijos pranešimas spaudai, Klimato kaita ir Lietuva, http: / / www.am.lt/VI/article.php3?article_id=6161, 2007-09-03.
} 
medžiagu judèjimui bei saugiam IAE eksploatavimui ar eksploatavimo nutraukimui. 2006 m. baigtas vykdyti PHARE projektas „Branduolinių ir radiaciniu avarijų valdymo stiprinimas Lietuvoje“", kurio igyvendinimo metu, peržiūrèti teisès aktai avarinio pasirengimo srityje, siekiant išvengti ekologinès katastrofos, t. y., užtikrinti ekologinį saugumą. Išleisti informaciniai leidiniai lietuvių ir rusų kalbomis visuomenei kaip elgtis radiacinių avarijų atvejais, sustiprintas techninis pasirengimas, paruošta mokymo metodika ir kt. 2006 m. atnaujinta radiacinio pavojaus perspejjimo sistemos (RADIS) matavimo įranga. Parengta trečioji IAE saugos gerinimo programa (SIP-3), kurią sudaro 115 saugos gerinimo priemoniu, kurios bus igyvendintos 2005-2009 m. laikotarpiu.

Vienas iš daugiausiai lèšu pareikalavęs projektas - pasirengimas perkelti pirmajame bloke nebaigtą išdeginti kurą i antrajį bloką, kuris pabaigtas $2006 \mathrm{~m}$. SIP-3 didelis dèmesys skiriamas ir IAE fizinio saugumo gerinimui, įsigyjamos ir įdiegiamos naujos saugos priemonès ${ }^{6}$.

Siekiant užtikrinti radiacinę saugą tvarkant radioaktyviąsias atliekas igyvendinama radioaktyviujų atliekų tvarkymo strategija, kurioje numatyti radioaktyviujų atliekų tvarkymo infrastruktūros sukūrimo uždaviniai ir valstybės įmonės Radioaktyviujuc atliekų tvarkymo agentūros 2006-2008 m. veiklos programa. 2006 m. baigtas igyvendinti PHARE projektas „Maišiagalos kapinyno saugos įvertinimas ir pagerinimas“, skirtas Maišiagalos radioaktyviujuc atliekų laidojimo punkto saugai gerinti. Radioaktyviujų atliekų kaupas uždengtas papildoma specialia dangu sistema, įrengtos naujos apsauginès tvoros, sumontuota fizinès saugos įranga. Vykdoma nuolatine Širvintų rajono Bartkuškio miške esančios uždarytos Maišiagalos radioaktyviuju atlieku saugyklos aplinkos stebėsena. Atliekant paviršiniam kapinynui potencialiai tinkančios aikštelès IAE teritorijoje geologinius tyrimus ir stebejjimus, užbaigti Stabatiškès aikštelès tyrimai ir parengta, suderinta su institucijomis ir derinama tarp valstybiu poveikio aplinkai vertinimo ataskaita, apimanti Apvardu, Galulaukès ir Stabatiškių aikšteles ${ }^{7}$.

Galima tvirtinti, kad gerai sutvarkyta Lietuvos Respublikos radioaktyviujų atliekų tvarkymo teisinė bazè, tinkamai suplanuotas IAE eksploatavimo nutraukimo darbai, patvirtinta nacionalinè radioaktyviuju atliekų tvarkymo strategija ir jos igyvendinimo planai, sukurta sistema tvarkyti pamestuosius radioaktyvius šaltinius. Tačiau dar laukia didelis darbas - būtina parinkti paviršinio kapinyno vietą, ji suprojektuoti ir pastatyti, užtikrinti eksploatavimo nutraukimo plano vykdymą ir tam reikalingas lěšas; privalu gerinti Maišiagalos radioaktyviujų atliekų saugyklos saugą, tęsti bendradarbiavimą su kaimyninèmis šalimis dèl branduolinès energetikos objektų statybos, įdiegti TATENA misijos rekomendacijas, tobulinant kapinynų vietos parinkimo ir statybos procesą.

\footnotetext{
${ }^{6}$ Radiacinès saugos centro pranešimas spaudai, Radiacinès ir branduolinès saugos užtikrinimas, 2005-02-09.

${ }^{7}$ Valstybinès atominès energetikos saugos inspekcijos pranešimas žiniasklaidai, Kaip gerinsime branduolinę sauga Lietuvoje, Nr. (21.4.11)22.1-360, 2006-05-26.
} 
Kaip gerinsime branduolinę saugą Lietuvoje? Europoje pasiektas gana aukštas branduolinès saugos lygis. Šalys vadovaujasi tarptautinès atominès energijos agentūros (TATENA) pagrindiniais branduolinès saugos reikalavimais, saugos standartais ir kt. techniniais dokumentais, pažangiausia patirtimi. Kiekvienoje šalyje branduolinè sauga užtikrinama remiantis tų šalių įstatymais, nacionaliniais reikalavimais ir siekiama, kad branduolinè sauga ateityje nuolat gerètų. $2006 \mathrm{~m}$. Briuselyje buvo pristatyta reaktorių saugos harmonizavimo ataskaita. Nustatyta, kad Europos šalyse 51 \% nacionalinių reikalavimų atitinka rekomenduojamus lygius. Europos atominėse elektrinėse net 88 \% rekomenduojamų lygių jau igyvendinta, o iki $2020 \mathrm{~m}$. planuojama pabaigti reaktoriu saugos reguliavimo krypčių harmonizavimo darbus.

\section{Ekologinio saugumo problemos ir rizikos veiksniai}

Atmosferos tarša šiltnamio efektą sukeliančiomis dujomis - viena svarbiausių klimato kaitos priežasčiu, o ją mažinti yra visos tarptautinès bendruomenès užduotis. 1990-2005 m. Lietuvoje išmetamų šiltnamio dujų kiekis sumažejo daugiau kaip perpus (nuo $48 \mathrm{mln}$. tonų iki $22 \mathrm{mln}$. tonu). Apie $35 \%$ šių dujų išmeta AB „Mažeikių nafta“ ir kitos energetikos sektoriaus įmonès, 21 \% tenka transportui bei $22 \%$ stambesnèms pramonès įmonėms: AB "Achema", $\mathrm{AB}$ „Naujasis kalcitas“, $\mathrm{AB}$ „Akmenès cementas“ ir kt., žemès ūkiui tenka 18 $\%$, o 7 \% tenka atliekų tvarkymui ir vandenvalai. Palyginus su didžiosiomis valstybėmis, Lietuvoje per metus išmetamų šiltnamio dujų kiekis sudaro labai mažą dali - 0,05 proc. pasaulinio kiekio. Didžioji taršos dalis tenka JAV (20 \%), t. y. kiekvienam šios šalies gyventojui tenka 25 tonos, ES gyventojui 10 tonų ir Lietuvos gyventojui apie 4 tonas.

Lietuva, kaip ir dar 164 pasaulio valstybės, ratifikavo Jungtinių Tautu bendrosios klimato kaitos konvencijos Kioto protokolą ir laikosi visų jo reikalavimų. Protokole numatyta, kad ES iki 2012-ujų metų i atmosferą išmetamų šiltnamio dujų kiekį sumažins 8 \% lyginant su $1990 \mathrm{~m}$. Viena iš priimtiniausių priemonių šiltnamio dujų išmetimams šalyje mažinti yra energijos taupymas, gamyboje diegiant naujas technologijas, modernizuojant elektrines ir katilines, plačiau naudojant atsinaujinančius energijos šaltinius, atnaujinant daugiabučius namus siekiant padidinanti jų energetinį naudingumą. Igyvendinant Kioto protokolo reikalavimus problemu gali kilti 2009 m., uždarius IAE, kai elektros energijai gaminti teks sunaudoti daugiau iškastinio kuro ir tokiu būdu i atmosferą bus išmetama daugiau šiltnamio dujų. Igyvendinant daugiabučiuc namų modernizavimo programą, planuojama iki $2020 \mathrm{~m}$. atnaujinti apie 80 \% (15 tūkst.) senų daugiabučių namų. Tai leis sutaupyti apie $30 \%$. šiluminès energijos ir sumažinti atmosferos taršą šiltnamio dujomis iki 400 tūkst. tonų per metus. Pastaraisiais metais vis labiau ryškèja neigiamas globalios klimato kaitos poveikis žemès ūkiui, todèl vis aktualesnis tampa šių reiškinių keliamos 
rizikos valdymas. Dabar galiojanti rizikos valdymo sistema, pagrista draudimo įmokų kompensavimu bei nuostoliu, patirtų dèl stichinių reiškinių, kompensavimu, neefektyvi.

ES pradejo veikti prekybos šiltnamio dujomis sistema (priemonè atmosferos taršai mažinti). 93 Lietuvos pramonès įmonès įtrauktos prekiauti „sutaupytais" taršos leidimais, jeigu į atmosferą išmeta mažiau teršalu, nei joms leista. Europos Komisija patvirtino nacionalinį apyvartinių taršos leidimu paskirstymo 2005-2006 m. planą. Lietuva per trejus metus gali išmesti $34 \mathrm{mln}$. tonų šiltnamio dujų ( $2005 \mathrm{~m}$. buvo leista išmesti $13,5 \mathrm{mln}$. tonu, o išmesta tik 6,6 mln. tonu, $2006 \mathrm{~m}$. leista 10,6 mln. tonu, o išmesta apie $7 \mathrm{mln}$. tonu).

Labai veiksmingas būdas šiltnamio duju kiekiui atmosferoje mažinti - gausinti mišku plotus. Miškai sugeria anglies dioksidą išskirdami deguonị ir yra geriausi atmosferos „,sanitarai“. Miškais apželdinti reikètų apie 196 tūkst. ha žemès ūkiui netinkamų ir apleistų žemių. 2002-2006 m. miškingumas išaugo 1,3 proc. ir per artimiausius 20 metu planuojama padidinti mišku plotus iki 3 \%. Žiemos metu miškuose išdygę grybai ir pražydusios žibuoklès - gamtos išdaigos, sietinos su klimato pokyčiais. Su klimato kaita susiję apie 90 \% visu gamtinio pobūdžio ekstremalių ivvykių. Tikriausiai klimatas šils dar labiau, bus ypač stiprių liūčiu, ilgalaikių sausrų ar staigių atlydžiu, gali pasikeisti ir dirvožemio struktūra. Visa tai smarkiai veiks ne tik Lietuvos gamtą, bet ir ekonominį bei socialini šalies vystymąsi - apskritai kiekvieno žmogaus gerovę.

Klimato pokyčių poveikị ypač stipriai jus jūros pakrantė. Siuo metu Baltijos jūros lygis ties Lietuvos krantais pakyla apie 6,5 mm per metus. Kyla pavojus, kad XXI a. pabaigoje kranto linija grèsmingai pasikeis ir bus užlieta ne tik jūros, bet ir Kuršių marių pakrantès dalis. Tokị pavojų pastaraisiais dešimtmečiais jau patyrẻ Palangos paplūdimiai, kurie prarasdami smèli katastrofiškai siaurëja. Kylantis jūros vandens lygis, audros ir uraganai toliau veiks Baltijos krantus, paplūdimius ir pareikalaus didžiulių investicijų krantų tvarkymui. Mokslininkai turi laiku ịvertinti, kaip klimato kaita atsilieps šalies ekosistemoms, bioįvairovei, vandens ištekliams, žemės ir miškų ūkiui, žmonių sveikatai ir kt. sritims ${ }^{8}$.

Kaip rodo Lietuvos gyventojų apklausa apie visuotinį atšilimą ir klimato kaitą, nemaža dalis $(49,5 \%$ ) visuomenès yra linkusi asmeniškai prisidèti prie klimato kaitos mažinimo. Apie šios problemos egzistavimą patvirtina 89,6\% respondentų ir teigia, kad pramonès išmetami teršalai turi didžiausią įtaką klimato kaitai, 19,2\% mano, kad transporto tarša yra prie svarbių veiksniu, tuo tarpu tik 7,7\% energetikos specialistų sutinka su tokiu teiginiu. Tačiau daugiau kaip trečdalis gyventojų linkę manyti, kad visi veiksniai vienodai veikia ir tai akivaizdu, matant šiltesnes žiemas, nereguliarius metų sezonus, neigiamą įtaką gyvūnams, kraštovaizdžiui, jūrinei aplinkai ${ }^{9}$. Taupydami energiją, sodindami

\footnotetext{
${ }^{8}$ Lietuvos Respublikos Aplinkos ministerijos pranešimas spaudai, Klimato kaita ir Lietuva, http:/ / www.am.lt/VI/article.php3?article_id=6161, 2007-09-03.

${ }^{9}$ Lietuvos Respublikos Aplinkos ministerijos pranešimas žiniasklaidai, Nemaža dalis Lietuvos gyventoju linkę prisideti prie klimato kaitos mažinimo, http://www.am.lt/VI/article.php3?article_ id $=6158 \% 20-\% 2014 k, 2007-02-26$.
} 
medžius, keliaudami ekologiška transporto priemone, renovuodami butą, dalyvaudami klimato kaitos mažinimo tarptautinėse akcijoje, naudodami ekonomiškos klasès įrangą ir bent retsykiais atsisakydami automobilio iš tikruju prisidètumème prie gerovès kūrimo ateities kartoms.

Šiuolaikiniam gyvenimo būdui būdingas istorinių analogijų neturintis žaliavų naudojimas ir tiek daug, kad sunku ir įsivaizduoti. Dabartinis energijos tiekimas grindžiamas iškastiniu kuru, kurio sunaudojimas lyginant su 1980 m. išaugo penkis kartus. Tyrimai rodo, kad pasauliniu mastu energijos vartojimas dvigubejja, todèl kyla klausimas, ar iškastinio kuro rezervų užteks ilgam bei kaip bus išspręstos aplinkos saugos problemos, susijusios su „šiltnamio“ efekto susidarymu. Kasmet žmonija išskiria į atmosferą $22000 \mathrm{mln}$. tonų $\mathrm{CO}_{2}$ ir šis kiekis pastoviai auga, keldamas pavoju globaliniam klimato stabilumui. „Šiltnamio efektas“ yra pagrindinè su energetika susijusi šiandieninė problema. Didèjant temperatūros pokyčių greičiui, ekologinès sistemos negali prisitaikyti prie klimato pokyčių (klimato atšilimas „pastumia“ gamtines juostas ị šiaurę) ir organizmai nespejja „migruoti“ ị jiems priimtinas klimatines zonas. Būtina reguliuoti šį procesą atsižvelgiant į gamtinès aplinkos poreikius. Negalima paneigti, kad $\mathrm{CO}_{2}$ išmetimu sumažinimas yra brangus procesas, mokslininkų skaičiavimu kaštai gali siekti 5JAV dolerius tonai, tačiau lyginti su taršos mažinimo kaštais ir taršos negrižtamomis pasekmèmis, tai vargu, ar turètų būti svarstoma. Ilgalaikius visuomenès klestëjimo tikslus gali užtikrinti tik darnus energetikos vystymasis, t. y. ekonominiu, socialiniu ir aplinkos saugos aspektu suderinta energijos gamyba ir vartojimas, energijos šaltinių pakeitimas tais, kurie atsinaujintų. Lietuvai atsinaujinančiujų energijos šaltinių vartojimas yra ypač aktualus, nes mes neturime pirminių energijos šaltinių.

Lietuvoje 2006 m. ekologinių rizikos veiksnių kitimo tendencijos buvo panašios, kaip ir 2005 m. Rizikos veiksniai atmosferos saugos sektoriuje, kurie veikẻ šalies ekologinę būklę, liko vis didėjantis automobilių skaičius, neefektyvios miestų eismo reguliavimo sistemos, aplinkkelių stoka. Vandens vartojimo saugos sektoriuje susidèvëję centralizuotų vandens tiekimo tinklai, netinkamos kokybės geriamas vanduo, nepatenkinama šulinių vandens kokybė, atliekomis užterštu teritorijų bei sąvartynų, neatitinkančių ES reikalavimų, gausa.

2006 m. padaugëjo ekstremalių situaciju, kai buvo užteršta aplinka. Galima prisiminti du didelius gaisrus, tai būtų miško gaisras Kuršių Nerijoje, kurio metu išdegė virš 250 ha kalnapušių miško ir gaisras AB „Mažeikių naftos" teritorijoje.

2006 m. Lietuvoje gaisruose žuvo 305 žmonès. Šis rodiklis yra vienas aukščiausių tarp Europos valstybiu ir turi tendenciją augti. Padaugëjo ir avarijų bei įvykių skaičius, kai žala aplinkai buvo nežymi (2006 m. - 102 atvejai, 2005 m. - 87). Daugiausia tai yra incidentai su naftos produktais ir cheminemis medžiagomis (net 61 atvejis).

2006 m. vasarą vyravusios meteorologinès sąlygos - lietaus stygius, aukšta oro ir dirvos temperatūra, didelès saulès spinduliuotės prietaka sudarè palankias sąlygas sausrai vystytis daugelyje Lietuvos rajonų. Stichinė sausra įsivyravo didesnëje negu 1/3 šalies teritorijoje. Susidarẻ labai didelis gaisru pavojus miškuose, nuseko paviršiniai vandens telkiniai, o sausros Lietuvoje periodiškai kartojasi ir su metais dažnejja. 


\section{Pirminio aplinkos užterštumo ịvertinimo ekstremalios situacijos ar avarijos vietoje pavyzdys}

2006 m., rugsẻjo 15 d., po vidurnakčio, Molètuose, padangų sandèlyje kilo gaisras. İvykio vietoje specialistai paèmé oro mėginius lakiujų organiniu junginiu koncentracijai nustatyti. Oro méginiai imti 30 ir $300 \mathrm{~m}$ atstumu nuo degančio sandèlio pavejjinèje pusèje ir išanalizuoti laboratorijoje. Nustatyta, kad 30 metrų atstumu nuo gaisro paimtuose mėginiuose etilbenzeno koncentracija viršijo vienkartinę didžiausią leistiną koncentraciją (toliau - DLK) nuo 2,5 iki 5,5 karto. Kitu junginiu, kuriems pagal Lietuvos higienos normą HN 35:2002 yra nustatytos didžiausios leistinos koncentracijos benzino, tolueno, 1,2,4-trimetilbenzeno koncentracijos neviršijo leidžiamų dydžių. Méginyje, paimtame $300 \mathrm{~m}$ atstumu, nẻ vieno teršalo koncentracija neviršijo didžiausiu leistinų koncentracijų.

Hidrometeorologijos tarnybos duomenimis, rugsëjo 15-osios naktį orus Lietuvoje lèmẻ aukštesnio slègio sritis, nelijo, pūtẻ labai silpnas nepastovios krypties vëjas. Tyrimų metu prie gaisro židinio užfiksuotas rytų, šiaurès rytu iki $1 \mathrm{~m} / \mathrm{s}$ vëjas. İvykio metu vyravo nepalankios sąlygos teršalų išsisklaidymui. Padangų sandèlis, kuriame kilo gaisras, yra Molètų miesto pakraštyje, todèl gaisro metu galëjusios išsiskirti kenksmingos medžiagos nepasklido po miestą. Taigi galima prieiti prie išvados, kad netoli gaisro židinio išmatuota didelè etilbenzeno koncentracija viršijo DLK; 300 metru atstumu pavejjinëje nuo gaisro židinio pusẻje matuotų lakiujų organinių junginių koncentracijos neviršijo DLK ir gaisrą užgesinus, ir likvidavus taršos šaltini, stebėti aplinką nèra būtinybės. Tačiau galime tik įsivaizduoti, kokios ekologinės pasekmės ir kokia grèsmė žmonių sveikatai būtu, jeigu teršalams išplisti po miestą būtų palankios sąlygos! Kai neužtikrinamas ekologinis saugumas kasdieniame gyvenime, tai gali labai pakenkti gyvenamajai aplinkai ${ }^{10}$.

\section{Ekologinis draudimas - rizikos mažinimo priemonè}

Ekologinès rizikos draudimą šiuo metu suprantame kaip įstatymo ar sutarties pagrindu kilusị teisinį santykị, kurio turinį sudaro tam tikrų ịvykiu sukeltos ekonominės žalos finansinis apmokëjimas tretiesiems asmenims - fiziniams ar juridiniams - dèl avarinio ir netikèto aplinkos užteršimo. Ekologinis draudimas galimas tik esant pakankamam skaičiui draudèjų, kuriems gresia

\footnotetext{
${ }^{10}$ Lietuvos Respublikos aplinkos ministerijos pažyma apie pirminị aplinkos užterštumo įvertinimą ekstremalios situacijos ar avarijos vietoje, http:/ / aaa.am.lt/VI/files/0.608884001158740632.doc, 2006-09-15.
} 
panaši tikimybė patirti žalą ir kurie nori sumažinti galimų nuostoliu riziką, sudarydami atitinkamus draudimo fondus bei atsiradus draudimo organizacijoms, sutinkančioms apdrausti riziką. Dar prieš dvidešimt metų nei teorijoje, nei praktikoje nebuvo kalbama apie ekologinę riziką bankinėse ir draudimo operacijose. Tik 9-ajame dešimtmetyje Pasaulio bankas pirmą kartą prabilo apie ekologinį saugumą. Viena iš svarbiausių bankų konkurencinès veiklos sferu tapo jų norai veikti ekologišką aplinką. Vakaru šalyse bankai, draudimo bendrovès, investiciniai fondai racionaliai priderino savo veiklą prie pasikeitusios rinkos situacijos reikalavimu, orientuodamiesi ị sparčiai didëjantį ekologinès paskirties investiciju augimą, nauju, su aplinkos kokybės palaikymu susijusių, bankinių produktų kūrimą ir diegimą bei apskritai pabrèždami jų veiklą motyvuojantį ekologinị veiksnị. Neabejotina, kad būtent ekologinis veiksnys skatins XXI amžiaus bankininkystės kokybinius pokyčius ir aplinkos naudos procesai, aplinkos kokybės palaikymas taps vis svarbesniu bankinių instituciju veiklos tikslu. Bankinių paslaugų rinka yra glaudžiai susijusi su draudimo paslaugų rinka ir draudimo bendrovių reakcija į ekologinių problemų paaštrèjimą buvo labai operatyvi. Šiandien atsakomybès už žalą aplinkai draudimas yra evoliucionavęs ị atskirą draudimo rūšși, kai bet kuri veikla gali būti padengta ivairiai jungiant atskirus draudimo polisus. Draudimo sektorius turi labai dideli poveikį kompanijų aplinkos saugos saugiai veiklai per draudimo sutarties reikalavimus. Paskutinio dešimtmečio finansinès atsakomybẻs už žalą aplinkai dydžiai stipriai išsiplètė. Dabar jie įtraukia: išvalymo kaštus, atsakomybę už žalą asmeniui bei nuosavybei, kaštus už atstovavimą teisme, verslo laikino nutraukimo nuostolius, vertès sumažejimą (trečios šalies nuosavybės dèl taršos poveikio), rangos atsakomybę. Šis draudimas pasidare daug tinkamesnis ${ }^{11}$.

\section{Ekologinis ženklinimas - viena iš ekologinio saugumo užtikrinimo prevencinių priemonių}

Ekologinis gaminių ženklinimas yra sertifikavimas tų gaminių ar paslaugu, kurie yra mažiau žalingi aplinkai ir sveikatai nei kiti tos pačios grupés produktai. Vartotojai tokius produktus gali atpažinti iš ekologinio ženklo - grafinio simbolio, pateikto prekès etiketëje, reklamoje ar kt. Źenklinimas nèra privalomas, tai pačiu gamintojų, importuotojų ar pardavejų pasirinkimas. Siekiant, kad gaminiai galètų būti žymimi ekologiniais ženklais, jie turi atitikti tam tikrus nustatytus kriterijus. Ekologinis ženklinimas mažina aplinkos taršą ir saugo sveikatą (ekologiniu ženklu žymimi tie gaminiai, kuriu gamybos metu naudojamos tokios žaliavos ir technologiniai procesai, kurie mažiau teršia ora, vandeni, dirvožemį bei sudaro mažiau atlieku, tokie gaminiai ir iš jų susidarančios atliekos nekenkia žmoniu sveikatai ir aplinkai); taupo gamtinius išteklius (nustatyti kriterijai atsižvelgia ị gaminių atliekų perdirbimo, antrinio

${ }^{11}$ Čiegis R., (1 nuoroda) 
panaudojimo galimybes, pakuotès kiekį. Be to, ženklintų produktų gamybos bei eksploatacijos metu sunaudojama mažiau elektros energijos, vandens ir kt.); leidžia patiems vartotojams pasirinkti mažiau kenksmingus aplinkai gaminius ar paslaugas ir tokiu būdu mažinti kenksmingą poveikį aplinkai ir sveikatai; didina pramonės įmonių konkurencingumą (mažinamos energijos ir žaliavų sąnaudos produkcijos vienetui, įmonės gali padidinti produktyvumą, o su aplinkos apsaugos mokesčiais mažẻja ir produkcijos savikaina). İmonėms atsiveria naujos galimybės, nes tai nulemia aiškus vartotoju prioritetų teikimas aplinkai ir mažai žalingiems sveikatai gaminiams. Lietuvoje ši tendencija dar nėra ryški, tačiau senosiose ES šalyse, kur aplinkos apsaugai skiriamas didžiulis dėmesys, rinkoje įsitvirtinti ir sẻkmingai konkuruoti gali tik įmonès, atsižvelgiančios į šiuos kriterijus.

Būtina paminèti ir gamintojų pareigą užtikrinti gaminių saugą. Teikiant ì rinką gaminius reikia tinkamai juos paženklinti ir pateikti vartotojams reikiamą informacija, kad jie galètų įvertinti su gaminiu susijusią riziką per visą numatomą vartoti laiką. Gamintojas, sužinojęs, kad gaminys nesaugus, nedelsdamas informuoja apie tai vartotojus ir nustatyta tvarka privalo pašalintiji iš rinkos, atlyginti vartotojui nesaugiu gaminiu padarytą žalą. LR produktų saugos įstatymas nustato valstybinio produktų saugos reguliavimo bei jų valstybinės saugos ekspertizès, produktų saugos valstybės ir visuomeninès kontrolès pagrindus, informacijos apienesaugius produktus teikimo ir perdavimo tvarka, gamintoju, platintojų ir paslaugų teikëju pareigas bei atsakomybę už nesaugių produktų teikimą į Lietuvos Respublikos rinką ${ }^{12}$.

\section{Ekologinio saugumo užtikrinimo programos uždaviniai, ịgyvendinimo priemonès, laukiami rezultatai}

Ekologinio saugumo užtikrinimo programos vienas iš tikslų - sumažinti ekologinio pavojaus riziką, užkirsti kelią neigiamam aplinkos poveikiui, įtvirtinti valstybės politikos prioritetus ekstremalių situacijų prevencijos srityje. Siekiant igyvendinti nustatytus tikslus, būtina užtikrinti ekologinį saugumą, garantuojant darnią ūkio plètrą ir sumažinti neigiamą ekstremalios situacijos poveikį aplinkai bei gyventojams. Jei gerintume pasirengimą operatyviai reaguoti į susidariusias ekstremalias situacijas, sudarytume materialinių techniniu ir kitų reikalingu priemonių bazę ekstremalioms situacijoms prognozuoti ir valdyti; teisinėmis ir organizacinėmis priemonėmis skatintume švaresnių (mažiau pavojingų aplinkai) gamybos būdų ir technologijų taikymą, tai galètume sẻkmingai įgyvendinti ES reikalavimus taršos prevencijos srityje. Informacijos apie ekologinį saugumą rinkimas, analizė ir jos teikimas tinkamu laiku visuomenei skatins bendradarbiavimą su kaimyninėmis valstybėmis ekologinio saugumo ir taršos prevencijos klausimais, o teisinių ir organizacinių sąlygu

\footnotetext{
${ }_{12}$ Aplinkos informacijos centras, Ekologinis ženklinimas, http://www.apicentras.lt/?pid=93, 2007.
} 
sudarymas tam, kad atsakingos institucijos optimaliai koordinuotų tarpusavio veiksmus, užtikrins ekologinį saugumą.

Programos igyvendinimo priemonès vandenų apsaugos srityje susijusios su užteršto vandens nuotekų valymo įrenginių modernizavimu, geriamojo vandens viešojo tiekimo tinklo infrastruktūros plètra, vandens išteklių stebėsenos, laboratoriniu tyrimu, duomenų kaupimo ir analizès sistemu tobulinimu. Atmosferos apsaugos srityje akcentuojamas siekis, kad atmosfera būtų kuo mažiau teršiama šiltnamio efektą sukeliančiomis dujomis, dideliuose deginimo irrenginiuose būtu diegiamos naujos technologijos su degimo produktų valymoįrenginiais; būtų sukurta transporto priemonių keliamos taršos kontrolès sistema bei įteisintos ekonominès ir administracinès transporto priemonių keliamos taršos reguliavimo priemonès ir būtų įdiegta modeliavimu pagrịsta atmosferos kokybės stebėsenos sistema.

Atlieku tvarkymo srityje orientuojamasi į moderniu regioninių komunalinių atliekų tvarkymo sistemų sukūrimą bei ES reikalavimus neatitinkančių sąvartynų uždarymą. Būtina sukurti pavojingų atliekų surinkimo ir tvarkymo sistemą, kuri užtikrintų aplinkai ir žmonių sveikatai saugų pavojingų atlieku tvarkymą. Skubiai parengti energijos gamybos iš atliekų programą ir pradèti ją vykdyti. Taikyti šiuolaikines panaudoto branduolinio kuro tvarkymo ir saugojimo technologijas, analizuoti galimybes jị palaidoti, taip pat plèsti šiuolaikinèmis technologijomis pagrįstą radioaktyviujuc atliekų tvarkymo infrastruktūrą.

Ekstremaliu situacijų valdyme reikia įvertinti, kaip atsakingos institucijos pasirengusios reaguoti ic ekstremalias situacijas, padidinti sausros ir potvynio Nemuno žemupyje prognozavimo efektyvuma, irengti seismologines stotis, užtikrinti tvenkinių hidrotechnikos statinių tinkamą naudojimą ir priežiūrą, parengti mišku ir durpynu gaisru prevencines priemones, ištyrinèti požemines karstines tuštumas ir sudaryti Siaurès Lietuvos karstinio regiono tuštumų žemèlapi, užtikrinti ekologiškai saugią urbanistinę plètrą karstinių reiškinių požiūriu, parengti pasirengimo reaguoti ị avarijas Baltijos jūroje investicinius projektus, atlikti papildomą naftos telkinio D6 įrenginiu eksploatavimo poveikio aplinkai vertinimą ir kt. ${ }^{13}$

Galime manyti, kad valstybe, igyvendinusi šias programines nuostatas, bus tinkamai pasirengusi ir tinkamai užtikrins ekologinị saugumą, naudos prevencines priemones bei tinkamai kontroliuos galimus grèsmés ekologiniam saugumui šaltinius.

\section{Lietuvos Respublikos civilinès saugos ir gelbejjimo sistema bei uždaviniai}

Civilinès saugos ir gelbẻjimo sistemos tikslas - paruošti visuomenę ekstremalioms situacijoms, t. y., užtikrinti sklandų perëjimą nuo kasdienès veiklos prie veiklos ekstremalių situacijų metu bei sumažinti valstybės ekonominius

\footnotetext{
${ }^{13}$ Lietuvos Respublikos Seimo nutarimas, Dél ekologinio saugumo užtikrinimo programos patvirtinimo, Valstybės žinios, 2005-10-01, Nr. 117-4226.
} 
nuostolius ekstremalių situacijų atvejais; išsaugoti žmonių gyvybę, sveikatą, turtą bei aplinką; skatinti visuomenès iniciatyvą šiose srityse ir stiprinti pasitikẻjimą civilinės saugos ir gelbejjimo sistemos veikla.

LR civilinès saugos ir gelbëjimo sistemą sudaro Vyriausybės ekstremalių situacijų valdymo komisija, Priešgaisrinės apsaugos ir gelbejjimo departamentas prie Vidaus reikalų ministerijos ir jam pavaldžios įstaigos, ministerijos, valstybės ir savivaldybių institucijos, savivaldybiu priešgaisrinės ir kitos civilinės saugos tarnybos, ūkio subjektai, įstaigos, aplinkos stebejjimo ir laboratorinès kontrolès tinklas.

Saugos ir gelbẻjimo sistemos uždaviniai:

- perspėti gyventojus apie gręsiančią ekstremalią situaciją, informuoti apie jos galimus padarinius ir priemones jiems likviduoti;

- vykdyti ekstremalių situacijų prevenciją;

- organizuoti gyventojų aprūpinimą individualiomis ir kolektyvinėmis apsaugos priemonèmis;

- žvalgyti ir žymèti pavojaus židinius;

- gesinti gaisrus, atlikti gelbejjimo darbus;

- palaikyti viešają tvarką nelaimès rajone; teikti medicinos pagalbą ir vykdyti visuomenès sveikatos priežiūrą ekstremalių situacijų atvejais;

- evakuoti žmones ir turtą iš pavojingų teritorijų; vykdyti sanitarinį švarinimą ir kitas kenksmingumo pašalinimo priemones;

- organizuoti laikiną nukentėjusiujuc apgyvendinimą bei materialinį aprūpinimą; organizuoti mirusiujų laidojimą;

- organizuoti nutrauktą būtiniausių komunalinių paslaugų teikimą; teikti pagalbą gyvybiškai svarbiems objektams išsaugoti;

- kaupti gyvybiškai svarbių materialinių vertybių atsargas;

- mokyti vadovus, darbuotojus, civilinès saugos ir gelbejjimo sistemos pajejgas bei gyventojus ekstremalių situacijų atvejais;

- tirti ir analizuoti ekstremalių i̇vykių priežastis ${ }^{14}$.

- Lietuvoje yra daug ekstremalių situacijų šaltinių, galinčių sukelti daugelio žmonių žūti ar pakenkti sveikatai. Ignalinos atominė elektrinė, daugiau kaip 250 chemiškai pavojingų objektu, pavojingų cheminiu medžiagu pervežimai, susisiekimo sistema, naftos pramonè bei naftotiekio tinklai (negalima atmesti teroro ir diversijos aktų galimybių). Ekstremalios situacijos gali būti:

- gamtinès - ryškūs klimatinių sąlygų pakitimai, sukeliantys stichines nelaimes, masinius mišku ir durpynų gaisrus, teologiškai pavojingus reiškinius, pavojingas arba masines epidemijas ir kt.;

- techninès - įvairių technologiniu procesu sutrikimai, dèl kurių kyla gaisrai, įvyksta sprogimai, patenka į aplinką cheminiai ir radioaktyvieji teršalai, griūva pastatai, įvyksta įvairių transporto priemonių avarijos,

\footnotetext{
${ }^{14}$ Priešgaisrinės apsaugos ir gelbëjimo departamento pranešimas spaudai, Civilinés saugos ir gelbëjimo sistema, http://www.vpgt.lt/index.php?-1847704799, 2007.
} 
energetikos, magistralinių vamzdynų avarijos ir kt. ekstremalūs įvykiai, būdingi pramonès objektams ir komunikacijoms;

- ekologinès - priežastys, sukeliančios sausumos būklès, atmosferos sudèties ir savybiu, hidrosferos būsenos pakitimus;

- socialinès - masinès riaušès ir neramumai, blokados, provokacijos, diversijos, teroro aktai, kariniai veiksmai Lietuvos ir kaimyninių valstybiu teritorijoje.

Ekstremalias situacijas taip pat gali sukelti avarija IAE bei avarijos kaimyninių valstybiu atominèse jègainèse; branduoliniai sprogimai; avarijos transporte pervežant radioaktyviąsias medžiagas (atliekas); įmonėse, sandẻliuose ar kt. statiniuose, kuriuose gaminamos, perdirbamos, laikomos, perkraunamos ar neutralizuojamos pavojingos medžiagos; avarijos geležinkeliuose, oro ir jūrų transporte, keliuose, magistraliniuose dujotiekiuose ir naftotiekyje; gaisrai ir sprogimai įmonèse bei gaisrais miškuose ir durpynuose; stichiniai/katastrofiniai/hidrologiniai reiškiniai (stiprus vëjas, pūga, tirštas rūkas, pralaužtos dambos, apsemtos miestų ir gyvenviečių teritorijos, automobilių keliai ir pan.).

Lietuvoje kuriama ir tobulinama ekstremaliu situacijų valdymo sistema, parengta valstybinės reikšmės ir pavojingų objektų registro kompiuterinè informacinė sistema, kuria siekiama vienoda elektronine forma kaupti informaciją apie Lietuvos Respublikos bei valstybinės reikšmės objektus, šią informaciją aktualizuoti ir teikti civilinès saugos uždaviniams spręsti. Registro objektai yra valstybinès reikšmès objektai (patvirtinti Lietuvos Respublikos Vyriausybės 2001 m. lapkričio 9 d. nutarimu Nr. 1343), pavojingi objektai (patvirtinti aplinkos ministro 1999 m. liepos 19 d. įsakymu Nr. 221) bei hidrotechnikos statiniai statiniai ir įrenginiai vandens ištekliams naudoti ir aplinkai nuo žalingo poveikio saugoti (užtvankos, pralaidos, hidroelektrinès, laivybos statiniai ir kt.) statiniai, keliantys užtvindymo pavojų. Vadovaujančioji ir centrinè registro tvarkymo įstaiga yra Priešgaisrinès apsaugos ir gelbẻjimo departamentas prie Vidaus reikalų ministerijos; teritorinès registro tvarkymo įstaigos yra apskričiu viršininkų administracijų civilinès saugos departamentai. Lietuvos Respublikos Seimas Nacionalinio saugumo strategijoje nustatè, kad turi būti sukurta bendra civilinès saugos ir gelbëjimo institucija, kuri būtu pavaldi Vidaus reikalu ministerijai - tokia sistema šiuo metu kuriama ir tobulinama.

\section{Aplinkos taršos asbestu prevencija (mažinimas)}

Asbestas dèl savo savybiu - atsparumo cheminėms medžiagoms ir ugniai, blogo šilumos ir garso laidumo - buvo plačiai naudojamas statybiniu medžiagu ir kitų gaminių (pvz., šiferio lakštų stogams, beslègiu vamzdžių kanalizacijos kanalams, termoizoliacinių medžiagu, naudojamų katilinėse, šiluminėse trasose, asbestinio audinio, naudojamo nedegios aprangos ir įvairių 
ekranų gamyboje, elektrinių laidų izoliacijai, automobilių stabdžių kaladèlių įdèklų) gamybai. Nuo 1961 metų Lietuvoje asbestcemenčių gaminių gamybai sunaudota apie 700 tūkst. tonų asbesto, kurio didžioji dalis sunaudota šiferio ir vamzdžiu gamybai. Dèl šios priežasties galime teigti, kad asbesto yra beveik visuose tarybiniu laiku statytuose pastatų stoguose, katilinėse, šiluminėse trasose. I Lietuva asbestas ir jo gaminiai patekdavo ir iš Rusijos. Igyvendinant ES reikalavimus, Lietuvoje naudoti asbestą ir jo gaminius uždrausta nuo $2005 \mathrm{~m}$. sausio 1 d., tačiau dèl plataus asbesto panaudojimo statiniuose ir toliau išlieka asbesto skaidulų iš pažeistų asbesto turinčių gaminių rizika visuomenės sveikatai. Kadangi nèra sistemingai kaupiama informacija apie asbesto turinčius gaminius, jų susidèvëjimo lygi, kiekius, vietoves, kuriose tikètinas didžiausias užterštumas asbestu, todèl sunku planuoti asbesto turinčių gaminių pašalinimo iš aplinkos darbų apimtis, finansavimo poreiki, nustatyti asbesto turinčių gaminių pašalinimo iš aplinkos prioritetus. Patikimų ir kokybiškų duomenų rinkimui būtini kompetentingi specialistai, gebantys identifikuoti asbesto turinčius gaminius, įvertinti jų keliamą riziką visuomenès sveikatai. Valstybinės atlieku apskaitos duomenimis 2004 metais susidarè ir sąvartynuose pašalinta apie 3000 tonu, o 2005 m. -738 tonos asbesto turinčių atliekų. Igyvendinant atliekų sąvartynų irengimo, eksploatavimo, uždarymo ir priežiūros po uždarymo taisyklių nuostatas, nuo 2009 m. liepos 16 d. bus uždraustas atliekų šalinimas ES reikalavimų neatitinkančiuose sąvartynuose. Uždarius šiuos sąvartynus, asbesto turinčias atliekas bus galima šalinti Vilniaus statybinių atlieku sąvartyne ir dviejuose regioniniuose sąvartynuose - Alytaus ir Kauno (Lapiu). Šiuose sąvartynuose numatoma įrengti atskiras asbesto turinčių atliekų šalinimo sekcijas, tačiau iki šiol Lietuvoje nėra nustatyti asbesto turinčių atliekų šalinimo sąvartynuose techniniai reikalavimai, todèl negalima užtikrinti saugaus šių atliekų sąvartynų eksploatavimo. Didžiausi asbesto keliamą riziką sveikatai patiria darbuotojai, vykdantys statiniu griovimo, remonto ir asbesto pašalinimo darbus. Darbuotojų apsaugos nuo asbesto keliamos rizikos reikalavimus bei asbesto sukeliamų sveikatos pakenkimų prevencijos priemones nustato darbo su asbestu nuostatai. Akredituota laboratorija vykdo asbesto tyrimus darbo aplinkos ore vadovaujantis asbesto skaidulų koncentracijos ore matavimo metodiką. Bendruosius kompetencijos reikalavimus įmonèms, vykdančioms statiniu, turinčių konstrukcijose asbesto, griovimo ar šalinimo darbus, taip pat teisiškai reglamentuotas. Galiojantys teisès aktai neužtikrina saugaus asbesto turinčiu gaminių pašalinimo iš aplinkos ir asbesto turinčiu atliekų sutvarkymo. Kadangi darbuotojai nėra pakankamai informuojami ir šviečiami apie asbesto keliamą riziką visuomenès sveikatai, saugaus darbo su asbestu reikalavimus, todèl vykdant statybas, atliekant griovimo darbus, asbesto turintys gaminiai dažnai sunkiai identifikuojami, o asbesto turinčios atliekos nèra atskiriamos nuo kitų atliekų ir gali patekti į atliekų šalinimo ar perdirbimo įrenginius. Dažnai pasitaiko, kad įmonès, vykdančios veiklą, susijusią su asbestu, nesilaiko darbo su asbestu nuostatų reikalavimu, t. y., nepateikia Valstybinei darbo inspekcijai informacijos apie įmonès kompetenciją darbuotojų saugos ir sveikatos srityje vykdyti tokius darbus, nevykdo asbesto plaukeliu koncentracijos matavimų darbo aplinkos ore. 
Asbesto turinčios šiferinès stogų dangos plačiausiai paplitusios mažaaukščiuose statiniuose kaimo vietovẻse ir rajonuose, kurių gyventojai gauna mažas pajamas ir neturi finansinių galimybių pakeisti šias dangas į neasbestines. Teikiama parama daugiabučių namų savininkams ir mažas pajamas gaunančioms šeimoms modernizuoti daugiabučius namus, įskaitant šių namų stogu kapitalinį remontą ar rekonstravimą, numatyta panaudoti ES struktūrinių fondų paramą. Siekiant padidinti pastatų energetinį efektyvumą ir sumažinti energijos vartojimą, ES struktūrinių fondų lèšomis numatyta finansuoti šilumos tiekimo tinklų ir sistemų modernizavimą, daugiabučių namų atnaujinimą probleminėse teritorijose bei modernizuojant viešosios paskirties pastatus. Be to, iš aplinkos bus pašalintas tik nedidelis asbesto turinčių gaminių kiekis. Gyventojai nesinaudoja įmoniu, vykdančių asbesto pašalinimo darbus, paslaugomis, vykdo šiuos darbus patys, neperduodami šio darbo kvalifikuotoms atliekų tvarkymo įmonèms, kadangi visuomenè nèra pakankamai informuota ir šviečiama apie asbesto keliamą riziką visuomenès sveikatai ir nėra sukurtas asbesto turinčiuc gaminių pašalinimo iš aplinkos skatinimo mechanizmas.

Aplinkos taršos asbestu prevencijos ir mažinimo nuostatos taikomo ūkinei veiklai, kurios metu sunaudojama daugiau kaip $100 \mathrm{~kg}$ asbesto žaliavos per metus. Veiklos vykdytojai privalo užtikrinti, kad asbesto tarša išmetant ji i a aplinkos ora, išleidžiant ị paviršinio vandens telkinius būtų kiek galima mažinama pačiame taršos šaltinyje. Kietos asbesto atliekos turi būti pakartotinai perdirbamos ir apdorojamos arba apskritai neleidžiama joms susidaryti. Gaminant asbesto cementą bei asbesto popierių ir kartoną yra nustatyti specialūs reikalavimai (pvz., visos susidarančios nuotekos turi būti valomos ir pakartotinai panaudojamos įrengiant apytakines vandens tiekimo sistemas). Asbesto taršos šaltinių monitoringas turi būti atliekamas periodiškai, t. y., nustatyta tvarka turi būti atliekami asbesto koncentracijos matavimai taršos šaltiniuose. ES Tarybos direktyvoje dèl aplinkos taršos asbestu prevencijos ir mažinimo (87/217/EEB) pabréžiama aplinkos taršos prevencijos ir mažinimo svarba. Kadangi asbestas priskiriamas pirmosios kategorijos teršalams, kuriuos reikia tirti, siekiant nustatyti jų toksiškumą ir galimus rimtus padarinius žmonėms bei aplinkai, ribojama mėlynojo asbesto ir jo skaidulų turinčių asbesto gaminiu prekyba ir naudojimas bei nustatomas specialus ženklinimas asbesto turintiems gaminiams. Numatytos nuostatos dèl dirbančių su asbestu darbininkų apsaugos nuo jo keliamo pavojaus bei kovos su pramonės įmonių keliama oro tarša priemonės ir reikalavimai. ES valstybès narès turètų imtis būtinu priemoniu užtikrinti, kad asbesto emisijos į atmosfera, jo išleidimas į akvatorijas ir kietos asbesto atliekos būtų kaip galima daugiau mažinamos jų susidarymo vietoje arba iš viso nebūtų leidžiama joms susidaryti, todèl tikslinga esamoms gamykloms skirti pakankamai laiko, kad jos galètų tas priemones igyvendinti.

İvertinant asbesto keliamą riziką visuomenès sveikatai, asbesto turinčiu gaminių panaudojimo ir pašalinimo iš aplinkos esamą situaciją, Lietuvos Respublikos Vyriausybė parengė Asbesto šalinimo programą, kurioje nustatyti tikslai, uždaviniai, numatytos teisinès, administracinės ir ekonominès priemonès programai igyvendinti. Programos priemonių igyvendinimo laikotarpis 
-2013 m. Patobulinus teisės aktus, reglamentuojančius asbesto turinčių gaminiu pašalinimą iš aplinkos, bus nustatytas reikalavimas pateikti informaciją apie asbesto turinčius gaminius ir šių gaminių saugų pašalinimą iš aplinkos statinių jau projektavimo etape, bus nustatyti asbesto turinčių atliekų šalinimo sąvartynuose techniniai reikalavimai, užtikrintas saugus asbesto turinčių gaminiu pašalinimas iš griaunamų ar rekonstruojamų statinių ir susidariusių atlieku šalinimas sąvartynuose. Sukūrus įmonių, vykdančių asbesto pašalinimo darbus, licencijavimo ir darbuotojų kvalifikacijos kẻlimo sistemą, bus sustiprinta asbesto turinčių gaminių pašalinimo kontrolè bei sumažinta asbesto keliama rizika darbuotojų sveikatai. Igyvendinus visuomenès informavimo ir švietimo priemones, pagerès visuomenès informavimas apie asbesto keliamą riziką visuomenės sveikatai, visuomenè žinos, kaip elgtis su asbestu turinčiais gaminiais, ir dažniau naudos kvalifikuotų įmonių vykdančių asbesto pašalinimo darbus, paslaugomis. Programos igyvendinimui nustatyti vertinimo kriterijai padidins galimybes efektyviau panaudoti ES struktūrinių fondų paramą.

Kol asbesto turintys statiniai, konstrukcijos ir gaminiai neliečiami, ši medžiaga didesnio pavojaus nekelia. Jis atsiranda ardant, laužant ar apdorojant, kai aplinkoje pasklinda labai smulkios, akiai nematomos skaidulos. Žmogui įkvèpiant asbesto skaidulas, jos lyg adatèlès susminga ị kvėpavimo takų audini, tapdamos nepagydomų vėžinių susirgimų priežastimi. Dèl asbesto poveikio per metus Europos šalyse užregistruojama apie 20 tūkst. mirčių nuo plaučiu vėžio, o pagal savo kenksmingumą jis prilyginamas arsenui ir gyvsidabriui. Jau 1976 m. asbestas įrašytas į tarptautinio vėžio tyrimo centro kancerogeniniu veiksnių sąrašą kaip kenksminga, vèži sukelianti medžiaga, tačiau sąlytị su asbestu ar jo turinčiais gaminiais dar turi daug žmonių. Asbesto yra beveik visų senesnių transporto priemonių, kranų, liftų ir kitų įrenginių stabdžių bei sankabų detalèse, ugniai atspariose sienose ir duryse, dažuose ir klijuose (pvz., koklių ir grindu plytelių), védinimo įrenginiuose, vamzdynuose (kaip izoliacinẻ medžiaga), karščiui ir ugniai atspariuose tekstilès gaminiuose, mikrobangų krosnelèse ir kt.

Net vienuolikoje ES Tarybos direktyvų kalbama apie asbesto turinčius gaminius arba atliekas. Dėl didelio patvarumo organizmas negali suskaidyti, pašalinti arba ištirpinti asbesto, kuris patenka į jo organizmą. Pavojingiausiais laikomi plaušeliai, ilgesni kaip 8 mikromilimetru ir plonesni kaip 1,5 mikromilimetru, nes jie gali pasiekti pačias tolimiausias plaučiu atšakas. Dèl savo plataus naudojimo pramoneje ir buityje, daugelyje vietų ore visą laiką sklando asbesto plaukelių. Jų galima rasti beveik visų žmonių plaučiuose. Rizika susirgti asbesto sukeliamomis ligomis didejja įkvepiant didelį asbesto plaukelių kiekị. Dulkès su asbesto plaukeliais yra biologiškai agresyvios. Plaučių audinyje įsmigę asbesto plaukeliai sukelia nekontroliuojamą vėžinių ląstelių augimą. Asbesto sukeliamos ligos negailestingai progresuoja, yra nepagydomos, o pirmieji ligos požymiai gali pasimatyti ar pasireikšti tik po 20-30 metų. Lietuvos Respublikos Vyriausybės nutarimu dèl asbesto ir jo turinčių gaminių importo, gamybos ir naudojimo ribojimo nuo: 
- $2001 \mathrm{~m}$. sausio 1 d. uždrausta naudoti lygius ir banguotus asbestcemenčio šiferio lakštus gyvenamuosiuose namuose ir visuomeninės paskirties objektuose;

- 2002 m. sausio 1 d. lygius ir banguotus šiferio lakštus draudžiama naudoti ir visuose kituose statomuose objektuose;

- 2003 m. sausio 1 d. uždrausta naudoti apdorotą asbestcemenčio pluoštą ir mišinius, daugiausia sudarytus iš asbesto bei jų dirbinius, išskyrus naudojamus civilinëje aviacijoje;

- $2004 \mathrm{~m}$. sausio $1 \mathrm{~d}$. uždrausta įvežti asbestą ir gaminti asbestcemenčio vamzdžius bei movas;

- 2005 m. sausio 1 d., vadovaujantis Europos teisės aktų nuostatomis, uždrausta prekiauti produktais arba medžiagomis, kuriu sudètyje yra asbesto ir jas naudoti (Direktyva 1999/77/EB);

- $2006 \mathrm{~m}$. balandžio $15 \mathrm{~d}$. visose ES šalyse ịsigaliojo griežtesnès priemonès, skirtos darbuotojams nuo asbesto skaidulu keliamo pavojaus apsaugoti (Direktyva 2003/18/EB, iš dalies keičianti Direktyvą 83/477/EB) $)^{15}$.

Nepaisant šios teisinės pažangos, išlieka praktinė problema kaip apsisaugoti nuo asbesto keliamo pavojaus atliekant šalinimo, griovimo, aptarnavimo ir eksploatacijos darbus.

\section{Išvados}

1. Ekonominè plètra išryškina globalines problemas (skurdą, karinius konfliktus ir kt.), konfliktai skatina pažeisti aplinką, o vèliau taip pažeista aplinka paaštrina socialinius konfliktus, todèl ekologiniu problemu atsiradimą, siekiant ekologinio saugumo užtikrinimo, reikia nagrinèti kaip atgalinių ryšių pasireiškimą tarp ekonominiu, socialinių ir aplinkos saugos šalies plètros komponentų.

2. Pagrindinėmis išorinėmis grėsmėmis išlieka trumpalaikès gaivalinės nelaimès: audros, ilgalaikiai šalčiai, liūtys, vejai bei gaisrai atvirose teritorijose. Būtina tiksliau identifikuoti prevencines priemones, kurios užtikrintų šiu grẻsmių išvengimo galimybes.

3. Esama aplinkos kokybè neatitinka reikalavimų darniam vystymuisi ir nėra patenkinama. Nuoteku valymas ir susidariusio dumblo tvarkymo problemos išlieka problema; neišspręstas specifinių atliekų tvarkymas; geriamojo vandens centralizuotas tiekimas nèra prieinamas didžiajai daliai Lietuvos gyventojų ir kt. Tik efektyvus ES struktūrinių fondų finansinės paramos panaudojimas gali užtikrinti šių problemų sprendimą. Būtina stiprinti administracinius gebẻjimus finansinei paramai įsisavinti visuose valstybės valdymo lygmenyse.

\footnotetext{
${ }^{15}$ Lietuvos Respublikos aplinkos ministerijos įsakymas, Dèl aplinkos taršos asbestu prevencijos ir mažinimo taisykliu patvirtinimo, Valstybės žinios, 2000-08-23, Nr. 70-2081; Asbesto šalinimo programa (projektas), www.am.lt/VI/files/0.941625001178192576.doc, 2007
} 
4. Prekių ir paslaugu apimtys turi didèti dvigubai greičiau negu gamtos išteklių naudojimas juos sukurti, todèl reikia sudaryti palankias sąlygas racionaliam gamtos išteklių naudojimui, jų atkūrimui, gausinimui bei apsaugai.

5. Grèsmès ekologiniam saugumui šaltiniai pagal savo pobūdị apibrèžti, tačiau nepakanka veiksmų ir priemoniu, kurios užtikrintų sveikos ir švarios aplinkos išsaugojimą, todèl pavojus ekologiniam saugumui išlieka.

6. Būtina įvertinti ekstremalių situacijų valdymo efektyvumą ir veiksmingumą. Atsakingos institucijos dažnai tik teoriškai pasirengusios reaguoti i ekstremalias situacijas, todèl prevenciniu pratybų organizavimas, visuomenès švietimas nuo mokyklos suolo turi tapti programine priemone strateginiuose šalies dokumentuose. Būtina kontroliuoti galimus grèsmés ekologiniam saugumui šaltinius.

7. Kuo skubiau parinkti vietą Maišiagalos radioaktyviuju atliekų paviršiniam kapinynui, siekiant užtikrinti radiacinę saugą tvarkant atliekas.

8. Ekonominiai, socialiniai ir aplinkos saugos aspektai turi būti suderinti sprendžiant energijos gamybos ir vartojimo klausimus, energijos šaltiniu pakeitimus tais, kurie atsinaujintų. Lietuvai atsinaujinančių energijos šaltinių vartojimas labai aktualus, nes neturime pirminių šaltiniu, todèl būtina nuosekliai vykdyti šalies strateginius įsipareigojimus šioje srityje.

9. 2006 m. Lietuvoje padaugèjo ekstremalių situaciju, kai buvo užteršta aplinka. Buvę incidentai susiję su naftos produktais ir cheminėmis medžiagomis, todèl būtina stiprinti šios veiklos kontrolę, analizuoti ES šalių patirti ir taikyti geros praktikos atvejus mūsų šalyje.

10. Ekologinès rizikos draudimas turi būti prieinamesnis. Draudimo sektorius turi turèti didelį poveikị kompanijų aplinkos saugos veiklai (per draudimo sutarties reikalavimus). Pasinaudojant verslo centrų ir asocijuotų verslo organizaciju potencialu, skatinti verslą drausti ekologinę riziką.

11. Produktų sauga rinkoje neužtikrinta, nes prasta kontroliuojančių institucijų veikla (ji daugiausia paremta vartotojų skundų analize). Produktu saugos kontrolès rinkoje stiprinimas turi užtikrinti gamintojo atsakomybės principo igyvendinimą.

12. Stiprinti ekologinio saugumo programos priemonių igyvendinimo stebėseną, nustatant kuo detalesnius indikatorius ir jei yra reikalas, tai juos papildyti naujais. Toks požiūris užtikrintų efektyvesnį biudžeto lèšų panaudojimą.

13. Asbesto ir jo gaminių keliamas pavojus žmonių sveikatai ypač aktualus. Išlieka praktinės problemos, kaip apsisaugoti nuo asbesto keliamo pavojaus atliekant jo tvarkymo darbus. Sukurti programą, kuri motyvuotu ir skatintu gyventojus išimti iš gyvenamosios aplinkos asbestą.

14. Ekologinio saugumo užtikrinimo priemonès valstybės ir savivaldybiu lygmenyje turi būti susijusios, kad užtikrintų visų Lietuvos gyventoju saugumą. 


\section{Literatūra}

1. Lietuvos Respublikos Vyriausybės nutarimas, Dėl ekologinio saugumo užtikrinimo programos igyvendinimo 2006-2010 metu priemonių plano patvirtinimo, Valstybès žinios, 2006-02-09, Nr. 16-552;

2. Lietuvos Respublikos Seimo nutarimas, Dėl ekologinio saugumo užtikrinimo programos patvirtinimo, Valstybės žinios, 2005-10-01, Nr. 117-4226;

3. Lietuvos Respublikos Seimo nutarimas, Dèl gamtos išteklių tausojimo ir apsaugos programos patvirtinimo, Valstybės žinios, 2007-03-10, Nr. 30-1095;

4. Lietuvos Respublikos aplinkos ministro įsakymas, Dèl aplinkos taršos asbestu prevencijos ir mažinimo taisyklių patvirtinimo, Valstybės žinios, 2000-08-23, Nr. 70-2081;

5. Lietuvos Respublikos Vyriausybės nutarimas (projektas), Dẻl asbesto šalinimo programos patvirtinimo, 2007;

6. R. Čiegis, „Ekologinis saugumas: nauji iššūkiai planetai“, Strateginė savivalda, ISSN 1648-5815 Strategic Self- Management 2006 Nr. 1(3);

7. Lietuvos Respublikos aplinkos ministerijos pranešimas spaudai, Klimato kaita ir Lietuva, 2007-09-03;

8. Lietuvos Respublikos aplinkos ministerijos pranešimas spaudai, Radiacinès ir branduolinès saugos užtikrinimas, 2005-02-09;

9. Valstybinės atominės energetikos saugos inspekcijos pranešimas žiniasklaidai, Kaip gerinsime branduolinę saugą Lietuvoje, Nr. (21.4.11)22.1-360, 2006-05-26;

10. Lietuvos Respublikos aplinkos ministerijos pranešimas žiniasklaidai, Nemaža dalis Lietuvos gyventojų linkę prisidèti prie klimato kaitos mažinimo, 2007-0226;

11. Priešgaisrinès apsaugos ir gelbejimo departamento pranešimas spaudai, Civilinès saugos ir gelbejjimo sistema, 2007;

12. Lietuvos Respublikos aplinkos ministerijos pažyma apie pirminį aplinkos užterštumo įvertinimą ekstremalios situacijos ar avarijos vietoje, 2006-09-15;

13. Aplinkos informacijos centras, Ekologinis ženklinimas, 2007. 